\title{
PENGARUH SENAM KAKI TERHADAP PENYEMBUHAN LUKA DIABETIK PADA PASIEN DIABETES MELLITUS DI RUANG RAWAT INAP RA 1 DAN RA 2 PENYAKIT DALAM RSUP H. ADAM MALIK MEDAN
}

\author{
Dewi Astuti Pasaribu, Septian Mixrova Sebayang \\ Program Studi Ilmu Keperawatan, STIKes Sumatera Utara \\ Email : dewiastutipasaribu@gmail.com \\ Program Studi Ilmu Keperawatan, STIKes Sumatera Utara \\ E-mail : septiansebayang716@gmail.com
}

\begin{abstract}
Diabetic foot ulcers (DFUs) are a serious complication of diabetes mellitus (DM) that can be slow to heal, result in repeated hospitalizations, require intense and costly treatment, and reduce the quality of life. The purpose of this study was to investigate the effect of foot exercises on wound healing in type 2 diabetic patients with a diabetic foot ulcer. Quasi-experimental study using before and after changes to wound healing in between February until May 2019.Thirty patients from an inpatient rooms with ulcers who met study criteria agreed to participate. Subjects were recruited by the researchers in the hospital where they received treatment. Data were collected using investigator-developed forms: patient information form and the diabetic foot exercises log. Patients in the intervention group received standard wound care and performed daily foot exercises for 3 week. Diabetic wound healing of the patients in the intervention were examined and measured at the 3rd weeks. To analyze and compare the data, frequency distribution, mean (standard deviation), and the paired samples $t$ test were used. The mean of diabetic wound healing were 3.50, 2.90, and 2.40 in the study intervention group in $1^{\text {st }}, 2^{\text {nd }}$, and $3^{\text {rd }}$ weeks, respectively. Significant differences were found between diabetic wound healing in pre-test and post-test group ( $p=0.041)$. An important finding in this study was the DFU area decreased more in those who exercised more. Findings suggest foot exercises should be included in the treatment plan when managing patients with diabetic foot ulcers.
\end{abstract}

Keywords: Diabetic foot exercises, diabetic foot ulcers, wound healing.

\begin{abstract}
Abstrak
Luka kaki diabetic adalah suatu komplikasi yang serius pada diabetes mellitus dimana dapat memperlambat penyembuhan, hospitalisasi berulang, membutuhkan pengobatan yang mahal dan menurunkan kualitas hidup. Tujuan penelitian ini adalah untuk mengetahui efek senam kaki terhadap penyembuhan luka pada pasien diabetes mellitus tipe 2. Jenis penelitian Quasi eksperimen digunakan untuk melihat perubahan sebelum dan sesudah penyembuhan luka dari Februari sampai Mei 2019. Tiga puluh pasien dari ruang inap dengan luka menjadi kriteria inklusi sebagai responden. Responden direkrut oleh peneliti di rumah sakit dimana pasien sedang menjalani perawatan. Pengumpulan data menggunakan kuesioner data demografi dan lembar observasi penyembuhan luka. Pasien akan diberikan latihan selama 3 minggu. Penyembuhan luka diabetic pada pasien akan dikaji dan diukur sampai minggu ke tiga. Untuk menganalisis dan membandingkan data, distribusi frekuensi, mean (standar deviasi), dan paired t test dilakukan. Mean penyembuhan luka diabetik diantaranya 3.50, 2.90 dan 2.40 pada kelompok intervensi pada minggu pertama, kedua, dan ketiga secara berurutan. Perbedaan signifikan penyembuhan luka diabetic antara kelompok pre-test dan post-test $(\mathrm{p}=0.041)$. Suatu temuan penting bahwa area luka kaki diabetic semakin menurun pada orang yang melakukan senam. Temuan ini juga senam kaki sebaiknya dimasukkan dalam rencana perawatan ketika merawat pasien dengan luka kaki diabetik. Kata Kunci : Senam kaki diabetik, luka kaki diabetik, penyembuhan luka
\end{abstract}




\section{PENDAHULUAN}

Saat ini gaya hidup modern dengan pilihan menu makanan dan cara hidup yang kurang sehat semakin menyebar ke seluruh lapisan masyarakat, sehingga menyebabkan terjadinya peningkatan jumlah penyakit degeneratif. Berdasarkan data Global Status Report on Non Communicable Disease (NCD) yang dirilis Organisasi Kesehatan Dunia, WHO (2016) disebutkan bahwa Diabetes Melitus menduduki peringkat ketujuh sebagai penyebab kematian pada kategori penyakit tidak menular. Rentang usia penderita diabetes pun bervariasi mulai dari 18 tahun hingga 70 tahun. Lalu studi terbaru dari International Diabetes Federation (2017) mengungkapkan, penderita Diabetes Melitus di seluruh dunia mencapai 424.9 juta orang. Adapun Indonesia masuk dalam urutan keenam negara dengan penderita diabetes terbanyak. Posisi pertama adalah Cina dengan 114,4 juta penderita, India sebanyak 72,9 juta jiwa, Amerika Serikat 30,2 juta jiwa, Brasil 12,5 juta jiwa, Meksiko 12,0 juta jiwa, dan Indonesia dengan jumlah penderita diabetes sebanyak 10,3 juta orang (IDF, 2017).

Diabetes mellitus mempunyai banyak komplikasi. Salah satu komplikasi umum diabetes adalah neuropati perifer diabetik. Gejalanya bervariasi, akan tetapi kehilangan sensasi pada satu atau kedua kaki sering menjadi tanda awal. Oleh karena itu, orang dengan neuropati perifer diabetik cenderung mempunyai luka kaki dan mempunyai risiko tinggi amputasi. The American Diabetes Association(ADA) telah merekomendasikan bahwa intervensi terbaik dalam pencegahan amputasi adalah menurunkan risiko luka kaki diabetik dan memberikan pendidikan perawatan luka yang sesuai pada pasien. Selain itu, senam kaki diadvokasikan sebagai langkah pencegahan yang penting dalam menurunkan risiko luka dan amputasi pada kaki diabetik (Kanchanasamut \& Pensri, 2017).

Diabetes mellitus adalah penyakit multisistem yang kronis berhubungan dengan produksi insulin yang abnormal, kerusakan pengunaan insulin, atau keduanya.
Komplikasi yang lama pada diabetes mellitus akan menjadi sebuah penyakit menghancurkan. Diabetes merupakan penyebab dari kebutaan pada orang dewasa, penyakit ginjal stadium akhirm dan amputasi pada ekstremitas bawah. Ini juga menjadi faktor utama dari penyakit jantug dan stroke. Orang dengan diabetes yang mempunyai penyakit jantung akan mempunyai risiko kematian dua sampai empat kali lebih tinggi dibandingkan orang tanpa diabetes. Risiko pada stroke juga dua sampai empat kali lebih tinggi diantara orang dengan diabetes. Disamping itu, ini diperkirakan bahwa 67\% orang dengan diabetes mempunyai hipertensi (Lewis, Dirksen, Heitkemper, \& Bucher, 2014).

Diabetes mellitus disebabkan oleh kurangnya insulin dan keparahan defisiensi insulin. Tanpa insulin, glukosa akan meningkat dalam darah, menyebabkan hiperglikemia, dimana kadar glukosa dalam darah tinggi. Hiperglikemia menyebabkan ketidakseimbangan cairan dan elektrolit dan gejala klasik diabetes: poliuri, polidipsi, dan polifagia. Saat defisiensi insulin, lemak terurai, melepaskan asam lemak bebas. Konversi asam lemak ke badan keton memberikan sumber energi alternatif. Karena badan keton, atau keton adalah pecahan produk asam lemak yang abnormal yang terkumpul dalam darah ketika insulin tidak ada dan kemudian mengakibatkan asidosis metabolik (Ignatavicius, \& Workman, 2013).

Gejala diabetes mellitus tergantung pada level hiperglikemia pasien. Gejala klasiknya meliputi $3 \mathrm{P}$, Poliuria, polydipsia, dan polifagia. Poliuria (peningkatan jumlah urin) dan Polidipsia (peningkatan rasa haus) terjadi sebagai hasil dari kehilangan cairan yang berlebihan berhubungan dengan diuresis osmotik. Pasien juga mengalami polifagia (peningkatan nafsu makan) yang disebabkan oleh status katabolik oleh defisiensi insulin dan pemecahan protein dan lemak. Gejala lain meliputi kelelahan dan kelemahan, gangguan penglihatan secara tiba-tiba, perasaan geli atau mati rasa pada tangan atau kaki, kulit kering, lesi kulit atau 
luka dengan penyembuhan yang lambat, dan infeksi berulang (Hinkle \& Cheever, 2014).

Luka diabetik adalah salah satu komplikasi pada diabetes mellitus. Ini telah diperkirakan bahwa 19\%-34\% pasien dengan diabetes mempunyai luka diabetik sepanjang hidupnya. Untuk menangani luka diabetik meliputi perawatan luka dengan surgical debridement, pemilihan dressing yang dapat meningkatkan kondisi luka yang moist, pengkajian vaskuler oleh ankle branchial index (ABI) dan kontrol glukosa (Everett, 2018). Luka diabetik berkaitan dengan neuropati perifer. Hal itu dimana terjadi penurunan densitas myelinated fibers karena hiperglikemia.

Memonitor perkembangan luka diabetik adalah merupakan salah satu sentral dari managemen luka diabetik. Dengan memonitor perkembangan luka diabetik, perawat dapat mengetahui status dari luka pasien, apakah terjadi deteriorasi (menjadi lebih parah) ke stadium selanjutnya ataukah luka telah membaik. Untuk memonitor luka ini perawat perlu menggunakan skala - skala yang mempunyai tingkat reliabilitas dan validitas yang tinggi.

Ada bukti yang penting bahwa efektivitas aktivitas fisik reguliar sebagai primer dan pencegahan sekunder diabetes dan kaki diabetik. Aktivitas fisik bahwa dapat dibuat sebagai latihan sktruktur, yang didefinisikan terapi latihan atau aktivitas fisik yang diadaptasi yang bertujuan untuk mencegah perkembangan atau progress pada faktor risiko pada luka kaki. Pada pasien diabetik, aktivitas fisik reguler dapat menurunkan berat badan, memperbaiki kontrol glukosa darah, dan sensivitas insulin, dimana dapat mennurunkan risiko perkembangan neuropathy. Aerobik dan latihan resistensi telah menjadi kegiatan yang secara tradisional dianjurkan untuk pencegahan dan pengelolaan diabetes (Francia, Gulisano, Anichini, \& Seghieri, 2014).

Senam kaki ini bertujuan untuk meningkatkan aliran darah ke ekstremitas bawah dan memperlancar mobilitas sendi. (Eraydin, 2018). Senam kaki pada pasien dengan luka kaki diabetik akan memfasilitasi pergerakan pada sendi dan otot, meningkatkan aliran darah pada area tertentu, dan memberikan perfusi yang adekuat pada luka. Senam ini juga dapat mempercepat penyembuhan luka, mencegah amputasi, meningkatkan kualitas hidup, dan menurunkan biaya. Asuhan keperawatan mempunyai peran yang penting dalam mempromosikan senam kaki pada pasien diabetik. Langkah-langkah senam kaki ditunjukkan pada Gambar 1.

Tujuan umum penelitian ini adalah untuk mengidentifikasi pengaruh senam kaki terhadap penyembuhan luka diabetik kepada pasien Diabetes Melitus di RSUP.H. Adam Malik Medan dan tujuan khusus mengidentifikasi penyembuhan luka pada kelompok kontrol dan intervensi serta menganalisis senam kaki terhadap penyembuhan luka diabetik.

Urgensi Penelitian dalam penelitian ini adalah pelaksanaan senam kaki akan memperlancar peredaran darah pada kaki diabetik dan mencegah terjadinya penurunan suplai darah pada saraf tepi dan gangguan persarafan terutama pada area kaki. Apabila terjadi perlukaan pada daerah kaki dengan kondisi kadar gula darah yang tinggi (pasien Diabetes Melitus) maka proses penyembuhan luka akan lama. Sehingga dengan dilakukannya senam kaki diabetik akan merangsang saraf saraf tepi, memperlancar peredaran darah, dan mempercepat penyembuhan luka. Sebaliknya, jika kondisi diabetik pada pasien diabetes mellitus tidak terkontrol maka kondisi luka akan semakin buruk serta beresiko untuk dilakukan amputasi. 


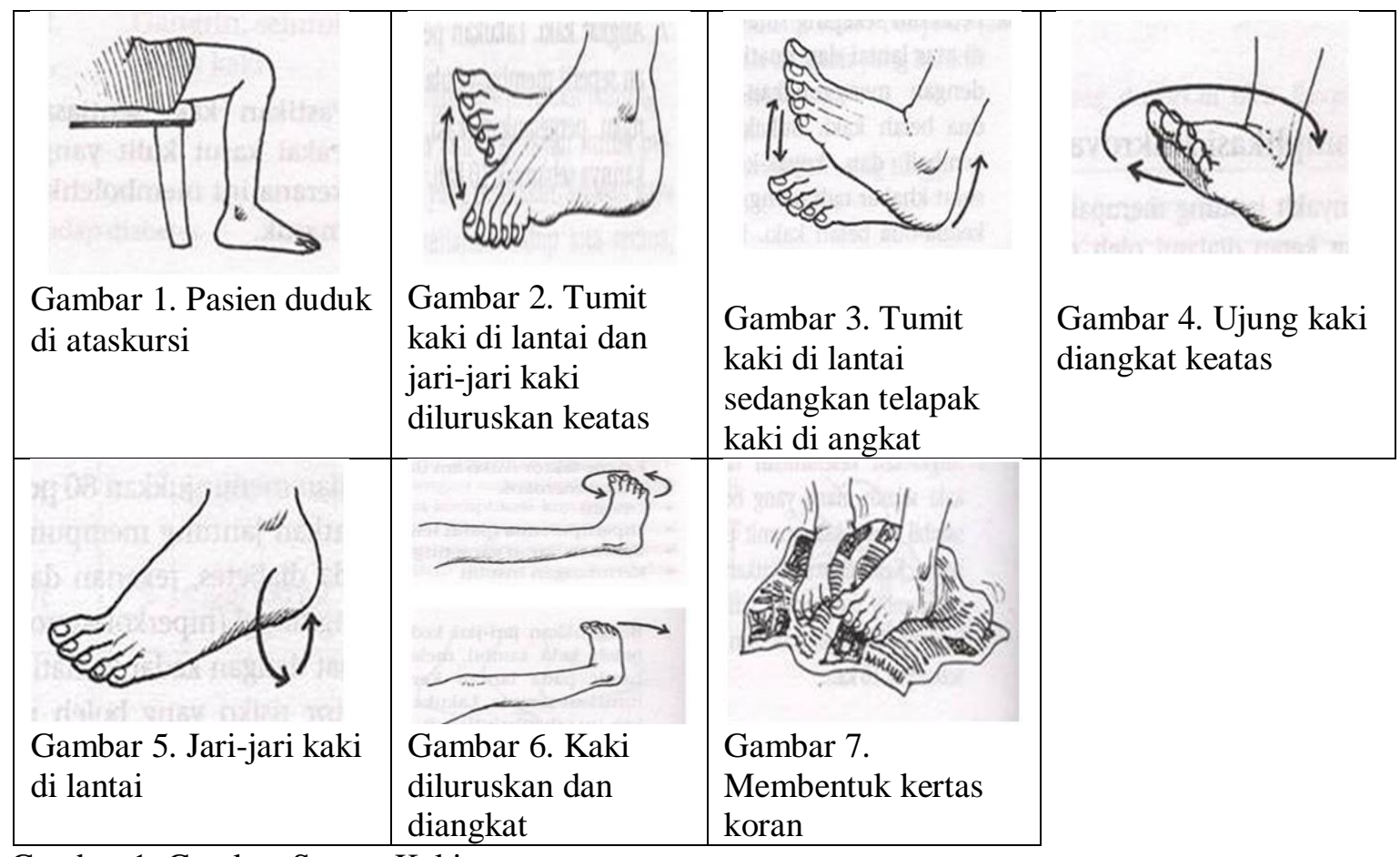

Gambar 1. Gerakan Senam Kaki

\section{METODE PENELITIAN Desain Penelitian}

Tujuan penelitian adalah untuk menganalisis pengaruh senam kaki terhadap penyembuhan luka pada pasien diabetes mellitus. Jenis penelitian adalah studi quasy eksperimen dengan satu kelompok dengan desain pretest-posttest, dimana pilihan yang sesuai ketika intervensi diharapkan dimana potensi menyebabkan sedikit kredibilitas (Polit \& Beck, 2012). Dalam penelitian ini hanya ada satu kelompok, dimana pada kelompok intervensi menggunakan senam kaki sebagai terapi komplementer dua kali sehari.

\section{Sampel}

Tiga puluh responden, dimana semua responden menjadi kelompok intervensi. Kriteria inklusi pada sampel diantaranya: pasien sedang menjalani perawatan di rumah sakit dan didiagnosa dengan diabetes mellitus tipe 2, tidak mempunyai masalah kesadaran. Kriteria eksklusi diantaranya: luka yang muncul bersifat sekunder pada trauma akut, luka muncul dengan luka bakar, luka dengan grade Wagner 3, 4, atau 5.

\section{Instrumen}

Wagner ulcer classification digunakan untuk mengukur penyembuhan luka diabetik. Wagner ulcer classification diberikan sebelum dan setelah dilakukan intervensi, dimana melakukan senam kaki. Wagner ulcer classification terdiri dari enam grade. Grade 0: Tidak ada luka terbuka, grade 1: Luka diabetik superfisial, grade 2 : Luka menyebar pada ligamen, tendon, atau fascia tanpa abses, grade 3 : Luka dalam dengan abses, grade 4 : Ganggren terlokalisasi pada kaki, dan grade 5 : Ganggren meluas pada seluruh kaki (Wagner, 1987).

\section{Analisis Data}

Data dianalisis menggunakan komputerisasi. Data dinilai menggunakan mean dan standar deviasi sebagai tes parametrik untuk membandingkan grade Wagner ulcer classification sebelum dan sesudah intervensi senam kaki. Tes normalitas data menggunakan KolmogorovSmirnov, dan paired t-test digunakan untuk menentukan efek senam kaki terhadap penyembuhan luka. 


\section{HASIL PENELITIAN}

Tiga puluh pasien diabetes mellitus direkrut yang memenuhi kriteria inklusi. Rata-rata usia dalam penelitian adalah 56.7 tahun, Tabel 1 menunjukkan karakteristik demografi dari pasien diabetes mellitus $(n=30)$ (semua pasien menerima senam kaki pada pengobatan). Mayoriras pasien adalah laki-laki (73.3\%), dengan pendidikan SMA $(50 \%)$, bekerja sebagai wiraswasta $(48.6 \%)$, dengan rata-rata usia terkena diabetes 5.23 tahun selama pengumpulan data.

Tabel 1. Frekuensi Karakteristik Demografi pada Pasien Diabetes Melitus yang Mempunyai Luka Diabetik (N=30)

\begin{tabular}{lc}
\hline Karakteristik & Frekuensi $(\%)$ \\
\hline Jenis Kelamin & $22(73.3)$ \\
Laki-laki & $8(26.7)$ \\
Perempuan & \\
Tingkat Pendidikan & $19(31.7)$ \\
SMP & $30(50.0)$ \\
SMA & $5(8.3)$ \\
Diploma & $6(10.0$ \\
Sarjana & $3(11.4)$ \\
Pekerjaan & $15(48.6)$ \\
PNS & $9(31.4)$ \\
Wiraswasta & $3(8.6)$ \\
Petani & \\
Pegawai swasta & Mean $=56.9$ \\
Umur Pasien Diabetes & Min $=29 ;$ max $=80$ \\
Melitus (Tahun) & \\
Umur Menderita Diabetes & Mean $=5.23$ \\
(Tahun) & Min $=2 ;$ max $=20$ \\
\hline
\end{tabular}

Tabel 2. Distribusi Penyembuhan Luka Diabetik pada Pasien Diabetes Mellitus di Rumah Sakit Adam Malik Medan ( $\mathrm{N}=30)$

\begin{tabular}{lccc}
\hline $\begin{array}{l}\text { Penyembuhan } \\
\text { Luka Diabetik }\end{array}$ & Mean (SD) & Median & $\begin{array}{c}\text { Min- } \\
\text { Max }\end{array}$ \\
\hline Minggu pertama & $3.50(1.07)$ & 3.00 & $2-5$ \\
Minggu kedua & $2.90(1.19)$ & 2.50 & $2-5$ \\
Minggu ketiga & $2.40(0.96)$ & 2.00 & $1-5$ \\
\hline
\end{tabular}

Tabel 2 menunjukkan bahwa rata-rata penyembuhan luka diabetik dalam penelitian ini 3.40 (1.07). Rata-rata penyembuhan luka diabetic pada minggu kedua dan ketiga adalah 2.90 (1.19) dan 2.40 (0.96) secara berurutan.
Tabel 3. Pengaruh Senam Kaki terhadap Penyembuhan Luka Diabetik ( $\mathrm{N}=30)$

\begin{tabular}{lccc}
\hline & \multicolumn{3}{c}{ Wagner Ulcer Classification } \\
\hline Kelompok & $\begin{array}{c}\text { Mean } \\
(\mathrm{SD})\end{array}$ & Min-Max & $p$ \\
& 2.90 & $2.40-3.40$ & \\
\hline Pre-test & $(0.50)$ & & \\
& 2.46 & $2.10-2.90$ & \\
\hline Post-test & $(0.40)$ & & \\
& & & \\
\hline
\end{tabular}

$* \mathrm{p}<0.05$

Paired t-test ditampilkan pada tabel 3 didapatkan nilai $\mathrm{p}=0.041$, yang diindikasikan bahwa ada perbedaan yang signifikan antara kelompok pretest dan posttest terhadap penyembuhan luka diabetik pada pasien diabetes mellitus dengan menggunakan Wagner Ulcer Classification, dimana ratarata kelompok pretest $(2.90 \mathrm{SD}=0.50$ lebih besar terhadap rata-rata pada kelompok posttest $(2.46 \mathrm{SD}=0.40)$. Ini dapat disimpulkan bahwa penelitian ini ditentukan secara statistik mempunyai perbedaan yang signifikan pada penyembuhan luka diabetik pada minggu pertama, kedua, dan ketiga penilaian saat pasien melakukan senam kaki $(p<0.041)$.

\section{PEMBAHASAN}

Temuan penelitian menyarankan bahwa senam kaki akan meningkatkan percepatan pemyembuhan luka dan mengindikasikan adanya klaitan antara waktu senam dengan kecepatan penyembuhan. Ketika penilaian awal tidak ditemukan adanya perubahan pada pasien pada rata-rata skor penyembuhan luka diabetik. Pasien yang mengalami penurunan dalam rata-rat penyembuhan luka kaki diabetik menurut pengukuran pada penilaian yang kedua. Pada penilaian yang ketiga ditemukan bahwa dilanjutkan pada pengalaman pada penurunan rata-rata skor penyembuhan luka diabetik.

Penyembuhan luka yang lambat dan lama merupakan hal yang umum dialami oleh pasien diabetik saat menerima perawatan yang standar. Pada pasien diabetik, ketidakcukupan perfusi karena angiopati dan neuropati menyebabkan pembentukan hipoksia pada jaringan. Hipoksia yang lama 
dan penyembuhan yang tertunda oleh peningkatan kadar oksigen radikal (Chadwick, 2013). Pada penelitian ini, responden mulai mengalami perubahan setelah minggu ketiga. Ini dapat menginterpretasikan bahwa temuan pendukung. Penyembuhan luka dimulai pada minggu kedua dan berlanjut pada minggu ketiga. Hal ini menyimpulkan bahwa ada perubahan yang terjadi sebagai hasil senam (aktivitas otot, peningkatan aliran darah di area luka, dan penurunan hipoksia)

Berdasarkan intensitas, senam dapat meningkatkan aliran darah sebanyak 3 sampai 25 kali. Menurut Keylock dan dkk (2008) alasan dimana senam meningkatkan penyembuhan luka berhubungan dengan peningkatan sirkulasi dalam jaringan luka, yang mana menstimulasi respon inflamasi. Akan tetapi, oksigenasi luka berkurang dan perfusi hipoksia terjadi pada luka karena aliran darah menurun pada pasien diabetik, ini secara luas dikenal bahwa senam kaki merupakan hal yang sangat penting pada pasien. Sejumlah latihan senam yang meningkat maka area luka berkurang. Ini merekomendasikan bahwa latihan akan meningkatkan aliran darah dan memperbaiki aliran oksigen ke dalam sel.

Peneliti yang menilai efek latihan senam pada pasien dengan DM tidak mempunyai luka kaki diabetik melaporkan bahwa senam kaki diabetik mempunyai efek positif terhadap neuropati, vaskulopati, karakteristik berdiri dan berjalan, keseimbangan tubuh, tekanan kaki, dan dorongan otot kaki (Chang, Chang, Su-Lun, \& Chen (2013). Flahr (2010) juga menilai efek latihan senam terhadap luka kaki diabetik dan menetapkan bahwa partisipasi pasien melakukan senam kaki pada rentang $70 \%$. Dalam penelitian ini juga melaporkan bahwa 30\% dari responden pada kelompok intervensi dan kontrol mendapat pemulihan penuh. Sebuah penelitian pada lansia oleh Emery dan dkk (2005) juga menunjukkan bahwa latihan dapat mempercepat pemulihan luka. Temuan penelitian ini mengkonfirmasi penelitian sebelumnya dan mengindikasikan bahwa senam kaki yang reguler mempunyai efek yang positif terhadap penyembuhan luka kaki diabetik dan sejumlah latihan sehari-hari dilakukan tanpa menggunakan beban juga dapat meningkatkan angka penyembuhan luka kaki diabetik.

\section{KESIMPULAN}

Temuan dari penelitian ini menyimpulkan bahwa senam kaki mempengaruhi penyembuhan luka pada pasien diabetik dan sebaiknya dijadikan sebagai satu bagian dari rencana pengobatan. Senam kaki diabetik tidak membutuhkan banyak alat, tidak ada biaya, dan latihan dapat dilakukan pada banyak waktu dan waktu yang ditentukan oleh pasien. Penelitian ini merekomendasikan bahwa senam kaki sebaiknya mendapat tempat yang utama dalam edukasi kaki diabetik dan secara rutin berkaitan ke dalam rencana pengobatan luka kaki diabetik.

\section{REFERENSI}

Chadwick, P., Edmonds, M., McCardle, J., \& Armstrong, D. (2013). International best practice guidelines: Wound management in diabetic foot ulcers. Wounds International, 4, 1 - 40

Chang, C.F., Chang, C.C., Su-Lun, H.S.L., \& Chen, M. (2015). Effects of Buerger exercise combined health-promoting program on peripheral neurovasculopathy among community residents at high risk for diabetic foot ulceration. Worldviews Evidence Based Nursing, 12, 145 153 . doi:10.1111/wvn.12091.

Emery, C.F., Kiecolt, G.J.K., Glaser, R., et al. (2005). Exercise accelerates wound healing among healthy older adults: a preliminary investigation . Journal of Gerontology Medical Science, 60, $1432-1436$.

Eraydin, S., \& Avsar, G. (2018). The effect of foot exercise on wound healing in type 2 diabetic patients with a foot ulcer: A randomized control study. Journal Wound Ostomy Continence Nursing, 45(2), 123-130 
Flahr, D . (2010). The effect of nonweightbearing exercise and protocol adherence on diabetic foot: ulcer healing: a pilot study . Ostomy Wound Manage, 56(10), 40 - 50

Francia, P., Gulisano, M., Anichini, R., \& Seghieri, G. (2014). Diabetic foot and exercise therapy: step by step the role of rigid posture and biomechanics treatment. Current diabetes reviews, 10(2), 86-99.

Hinkle, J. L., \& Cheever, K.H. (2014). Brunner \& Suddarth's textbook of medical-surgical nursing. Thirteenth Edition. Philadelphia: Wolters Kluwer Health/Lippincott Williams \& Wilkins.

Ignatavicius, D. D., \& Workman, M. L. (2013). Medical-surgical nursing: Patient-centered collaborative care. St. Louis: Elsevier Saunders.

International Diabetes Federation (2017). IDF Diabetes Atlas. Eighth Edition. Diunduh pada website http://www.idf.org pada tanggal 19 April 2019

Kanchanasamut, W., \& Pensri, P. (2017). Effect of weight-bearing exercise on a mini trampoline on foot mobility, plantar pressure, and sensation of diabetic neuropathic feet: a preliminary study. Diabetic Foot \& Ankle, 8(1), 1-10

Keylock, K.T., Vieira, V.J., \&Wallig, M.A., et al. (2008). Exercise accelerates cutaneous wound healing and decreases wound inflammation in aged mice . American Journal Physics Regular Integral Complementary Physiology, 294 (1), R,179-184 . doi:10.1152/ajpregu.001 77.2007.

Lewis, S., Dirksen, S., Heitkemper, M., Bucher, L. (2014). Medical-Surgical Nursing: Assessment and Management of Clinical Problems. Ninth Edition. St. Louis: Elsevier

Polit, D. F., \& Beck, C. T. (2012). Nursing research: Generating and assessing evidence of nursing practice. Ninth
Edition. Philadelphia: Lippincott Williams \& Wilkins.

Reyes, J., Reimer, T.T., Parker, E., Muller, B., Laroche, H. (2017). Factors influencing diabetes selfmanagement among medically underserved patients with type II diabetes. Global Qualitative Nursing Research, 4, 1-13

Wagner, F.W. (1987). The diabetic foot. Orthopedics, 10(1), 163-172

World Health Organization (2016). Global report on diabetes. Geneva: WHO Press

World Health Organization (2018). Guidelines on second- and third-line medicines and type of insulin for the control of blood glucose levels in non-pregnant adults with diabetes mellitus. Diunduh pada website http://www.who.int pada tanggal 19 April 2019 